University of Tennessee College of Law

Legal Scholarship Repository: A Service of the Joel A. Katz Law Library

\title{
2016-2017 Oxford Business Law Blog Round-Up: Most Read Opinion Pieces
}

Maurice Stucke

Follow this and additional works at: https://ir.law.utk.edu/utklaw_facpubs

Part of the Law Commons

\section{Recommended Citation}

Stucke, Maurice, "2016-2017 Oxford Business Law Blog Round-Up: Most Read Opinion Pieces" (2017). UTK Law Faculty Publications. 206.

https://ir.law.utk.edu/utklaw_facpubs/206

This Article is brought to you for free and open access by the Faculty Work at Legal Scholarship Repository: A Service of the Joel A. Katz Law Library. It has been accepted for inclusion in UTK Law Faculty Publications by an authorized administrator of Legal Scholarship Repository: A Service of the Joel A. Katz Law Library. For more information, please contact eliza.boles@utk.edu. 


\title{
2016-2017 Oxford Business Law Blog Round-Up: Most Read Opinion Pieces
}

Contributors:

\author{
John Armour \\ Horst Eidenmüller \\ Pavlos Eleftheriadis \\ Luca Enriques \\ Ariel Ezrachi \\ Cheng Lim \\ Bruno Meyerhof Salama \\ Calum Sargeant \\ TJ Saw \\ Maurice Stucke
}




\section{6-2017 Oxford Business Law Blog Round-Up: \\ Most Read Opinion Pieces}

\section{Abstract}

On 14 March 2017, the Oxford Business Law Blog (OBLB) marked its first anniversary. Since its inception, it has published over 600 posts from academics and practitioners from across the world and has reached readers from over 170 countries. The purpose of this collection is to celebrate submissions created especially for publication on the OBLB: it comprises the ten most-read opinion pieces published on the OBLB in its first year. Corporate scandals, law and technology, and Brexit are the recurring themes.

Keywords: Antitrust, Blockchain Brexit, Capital Markets Union, Competition, Corporate Governance, Corporate scandals, Law and Technology, Prospectus Regulation, Smart Contracts 


\section{TABLE OF CONTENTS}

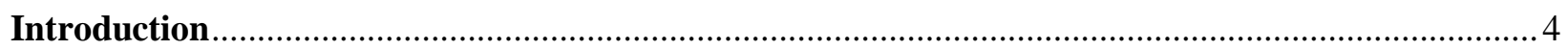

Volkswagen's Emissions Scandal: Lessons for Corporate Governance? (Part 1), John Armour ......... 5

Volkswagen's Emissions Scandal: Lessons for Corporate Governance? (Part 2), John Armour ......... 8

Douglass North and Brazil's “Car Wash” Scandal, Bruno Meyerhof Salama .................................. 11

The Rise of the Machines - How Automated Digital Assistants Can Reduce Competition (and the

Cash in Your Wallet), Ariel Ezrachi \& Maurice Stucke ........................................................................ 14

Smart Contracts: Bridging the Gap Between Expectation and Reality, Cheng Lim, Calum Sargeant \&

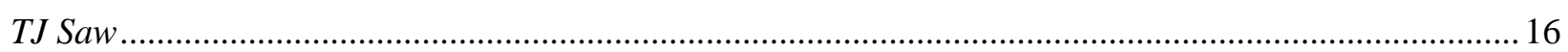

Brexit to the European Economic Area: What Would It Mean?, John Armour ...............................2

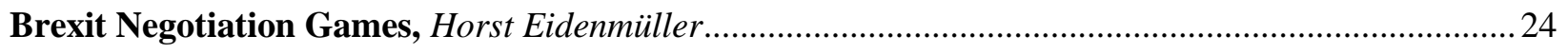

A New Referendum is a Constitutional Requirement, Pavlos Eleftheriadis .....................................22

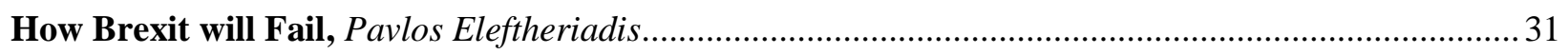

EU Prospectus Regulation: Some Out-of-the-Box Thinking, Luca Enriques .................................... 35

2016-2017 Oxford Business Law Blog Round-Up: Most Read Opinion Pieces 
On 14 March 2017, the Oxford Business Law Blog (OBLB) marked its first anniversary. One year ago, we set out to create a leading and truly international forum for the exchange of ideas and reporting of new developments in business law. Since then, we have published over 600 posts from academics and practitioners from across the world and have reached readers from over 170 countries.

The OBLB is now a firmly entrenched part of the Oxford Law Faculty's Business Law Hub. The OBLB is edited by Luca Enriques, Jennifer Payne (on leave), Kristin van $\underline{\text { Zwieten and Horst Eidenmüller, with associate editors Clara Martins Pereira, Konstantinos }}$

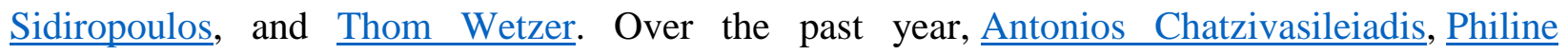

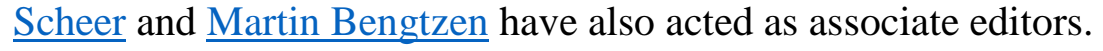

We would like to thank our contributors and ever-growing readership, as well as our sponsor Travers Smith, for their support and engagement. We look forward to another year of interesting contributions and fascinating discussions.

The purpose of this collection is to celebrate submissions created especially for publication on the OBLB. As such, this paper consists of a compilation of the ten most-read opinion pieces published on the OBLB in its first year. Corporate scandals, law and technology, and Brexit are the recurring themes. In this context, and for reasons of coherence and consistency, the pieces included in this paper are arranged in a thematic order.

Horst Eidenmüller

Luca Enriques

Jennifer Payne

Kristin Van Zwieten

Oxford, 15 March 2017 


\section{Volkswagen's Emissions Scandal: Lessons for Corporate Governance? (Part 1)}

\section{JOHN ARMOUR}

Even hardened cynics were shocked by the revelations in September that Volkswagen had programmed its diesel cars to defeat emissions tests. Whilst it was no secret that manufacturers attempted to 'game' these tests, what was astonishing about VW's behaviour was the scale and method of their deceit. The technology VW used for cleansing Nitrous Oxide emissions entailed a trade-off against fuel economy and performance, which VW's engineers and programmers had decided to manage by introducing two distinct driving 'modes' into the car's software: a 'best behaviour' mode that complied with US Nitrous Oxide emissions requirements, and another for all other circumstances. The cars' systems were smart enough to detect whether they were undergoing the highly predictable and stylised requirements of the US Environmental Protection Agency (EPA)'s tests, and to put themselves on best behaviour accordingly. The trade-offs were significant, however: the cars emitted up to 40 times more Nitrous Oxide during normal circumstances than under test conditions. About 500,000 vehicles were affected in the US, spanning the model years 2009-16. The tactic was used in other markets as well, raising the total number of affected vehicles to approximately 11 million worldwide.

Nitrous Oxides and particulates, a by-product of diesel combustion, are harmful for human health. Some analysts suggest that the additional pollution from VW's cars would have led to up to 100 additional deaths in the US alone from respiratory-related illness. To bring this problem home, note that 1.2 million affected cars were sold in the UK - more than twice as many as across the entire US. It's worth noting that annual average levels of Nitrogen Dioxide in Oxford High $\underline{\text { Street }}$ are $25 \%$ above the maximum levels permitted by EU law and considered 'safe' according to $\underline{\mathrm{WHO}}$ guidelines.

At this point, it remains unclear precisely how and why VW came to do this. US law firm Jones Day have been retained by VW to conduct an internal investigation, the results of which are due in the fourth quarter of 2016. VW's official line is that this was the result of the actions of a few engineers and programmers. Let's call this the 'rogue technicians' theory. However, with such a large number of vehicles, over a period of about seven years, it seems - as was argued in a recent post by J.S. Nelson-more plausible that senior management might have been aware of the scheme (or warning signs of it) at some point prior to its revelation. Let's call this the 'management inaction' theory. 
Whether it was rogue technicians or management inaction, it appears likely that cost savings were a key motivation. VW's competitors in selling diesel cars into the US market, BMW and Mercedes, developed a more expensive technology for cleansing diesel fumes of particulates and Nitrous Oxide, known as urea filtering. By choosing not to license this technology from Mercedes, analysts estimate VW could have saved up to $\$ 4.8$ bn worldwide.

Although this may seem a large sum, it is far smaller than VW's likely losses as a result of the scandal. VW faces a bevy of lawsuits from all over the world. Details of their expected quantum emerged in late April from VW's 2015 Annual Report and the announcement of an agreement in principle regarding a settlement with US authorities and class-action lawyers, under which VW reportedly agrees to repair or buy back the cars sold in the US with the illegal software, and to pay additional compensation. There are still many uncertainties regarding liability, as the agreement apparently only covers civil litigation in the US. In addition, the US Department of Justice has opened a criminal investigation, and civil, criminal and/or administrative actions have been commenced in many other countries.

VW's 2015 Annual Report announced provisions totalling $€ 16.4$ billion ( $\$ 18.4$ billion) for the clean-up and legal costs, including $€ 7.0$ billion ( $\$ 8.0$ billion) dollars for "legal risks" and a further $€ 1$ billion ( $\$ 1.2$ billion) for contingent liabilities. VW also began a product recall in the EU of cars sold with affected engines.

An interesting question is the extent to which, over and above the costs of liability, the recall and lost sales of non-compliant vehicles, VW has suffered further reputational losses. In the finance literature, 'reputational losses' are often taken to mean the cost to a company of people being less willing to trade with it - for example, having to lower its prices to shift product, or raise promised returns in order to raise capital. Such a shift can be triggered by the revelation of information that shows the company has a propensity not to keep its promises. But prior literature (Karpoff et al, 2005; Armour et al, 2010) finds that reputational effects of this sort are only triggered where the firm is revealed to have harmed parties who trade with it: where the harm imposes costs on third parties (e.g. the environment) then there is no stock price movement beyond the amount of the expected legal liability.

VW's stock price fell rapidly by $40 \%$ from its pre-scandal position, although it subsequently regained ground, now wavering at just under $20 \%$ down. This suggests the market's estimate of VW's likely losses is similar to the firm's provisions, at around $\$ 18$ billion. As a result, it doesn't seem that VW's case bucks the trend of purely environmental harms (as opposed to uncompensated harms to customers) not triggering reputational losses.

Given these losses, cheating was clearly a very bad thing for VW to do from an ex post perspective. But what about ex ante? This really depends on expectations about the probability of getting caught, and attitudes to risk. Consider first the (highly implausible) idea that the decision to cheat was in fact deliberately taken by management, assuming that the benefit was $\$ 5 \mathrm{bn}$ and the costs were $\$ 18 \mathrm{bn}$. This would have a positive expected return for VW provided that the probability of getting caught was less than approximately $25 \%$. Now consider the (much more plausible) position of a CEO who has a whiff that something may be amiss amongst junior engineers. He can 
either pursue an internal investigation, which will alienate engineers and may reveal wrongdoing. Or he can do nothing and press on regardless. The problem is that an internal investigation will surely increase the likelihood that the firm will get caught for any prior misconduct. If the CEO judges the initial probability of getting caught to be low, it is easy to see that it may maximise expected profits to turn a blind eye, rather than draw attention to a potential problem.

Of course, executives are risk averse, and so the option of cheating will seem less attractive. Nobody wants to lose their job under a cloud, or what is worse, face potential personal liability for criminal or negligent misconduct. This provides a nice introduction to the challenging questions the VW case poses for corporate governance. Why was it that risk-averse individuals amongst the management might have failed to investigate potential smoking guns? My second post on VW will further comment on the corporate governance implications of the emissions scandal and provide my answer to this question.

Date of Publication: 17 May 2016 


\section{Volkswagen's Emissions Scandal: Lessons for Corporate Governance? (Part 2)}

\section{JOHN ARMOUR}

In Part 1 of this post, I posed the question why risk-averse managers at VW might have failed to launch an internal investigation into any potential smoking guns during the company's prolonged and extensive emissions cheating. The answer, I would hazard, has to do with high-powered incentives. We tend to think of these as being a peculiarly problematic feature of Anglo-American corporations, with dispersed share ownership. In these firms, high-powered incentives in the form of heavily performance-related pay are conventionally deployed as a way of encouraging managers to be less risk averse with respect to business decision-making. The 'performance' criterion is normally defined by reference to the stock price, and it is 'high powered' because it responds aggressively to changes in the criterion. This is known to give rise to problems when it comes to compliance with corporate obligations imposed for purposes other than to maximise shareholder value: think of Enron, or banks prior to the financial crisis.

What the VW case exposes is that high powered incentives can be linked to compliance problems, even in firms that do not ostensibly have a culture of pursuing 'shareholder value'. Like all large German firms, VW had a two-tier board structure. VW's CEO, Martin Winterkorn, had a pay package that was heavily tilted towards variable pay. In 2014 , he took home $€ 16 \mathrm{~m}(\$ 18.3 \mathrm{~m})$, of which only $€ 2 \mathrm{~m}(\$ 2.3 \mathrm{~m})$, or $12.5 \%$, was fixed compensation. The heavy tilting towards performance related pay was common across members of VW's Vorstand, or Management Board. While executives' variable pay was not tied directly to the share price, it was linked closely to a number of metrics including operating profits, sales growth, customer satisfaction and employee productivity and satisfaction. This is consistent with the publicly-announced goal for VW for many years, namely growth: the goal was to make VW the largest car maker by sales in the world, which it ironically achieved in the first half of 2015, only to lose again in the wake of the scandal.

Financial incentives were not the only high-powered incentives acting upon senior VW executives. There will also have been intensive monitoring by the Aufsichtsrat, or Supervisory Board. Unlike an Anglo-American corporations' boards, German supervisory boards are staffed with representatives of major shareholders and labour. Thus VW's Aufsichtsrat of 21 had 5 members appointed by the Porsche family, the controlling shareholder, 2 appointed by the Qatar Sovereign wealth fund (which holds a 17\% stake), 2 appointed by the state of Lower Saxony (holding a 20\% stake), 10 appointed by employees, trade unions, and middle management. The 
other two comprised the Supervisory Board's venerable former Chairman, and a single independent. Growth was an ambition that pleased both stakeholder groups dominating the Aufsichtsrat, the controlling shareholders and the employees

Astonishingly, the bias toward performance pay was shared by VW's Aufsichtsrat. The Chair of the Aufsichtsrat, until April 2015 Ferdinand Piëch, took home $€ 1.5 \mathrm{~m}$ in 2014, of which only $€ 200,000$ (13\%) was fixed; this ratio was similar across the entire Aufsichtsrat. The Aufsichtsrat's variable pay is expressly linked by $\S 17$ of VW's Satzung, or Articles of Association, to shareholder dividends.

Although European executives are usually thought to earn less than their counterparts in the US, it is notable that Winterkorn's package was very similar to the total amount earned by Mark Fields, the CEO of Ford $(\$ 18.6 \mathrm{~m})$ and more than that of Mary Barra, the CEO of GM $(\$ 16.2 \mathrm{~m})$, in the same year. Financial incentives and close monitoring of performance are likely additive in terms of their impact on executive behaviour. Thus the intensity of the combined incentives might have been even stronger than those faced by a US executive. In short, highpowered incentives can give rise to perverse incentives in firms without dispersed share ownership, and where performance targets are not defined solely by reference to the share price.

What also emerges starkly from the VW affair is the importance of distinguishing between agency costs and externalities in discussions of corporate governance. Conflicts of interest between managers and shareholders are an agency cost. But so too are conflicts of interest between employees and shareholders. Harm caused to the environment, or any other interest external to the corporation, however, is an externality. Simply because a company's structure is designed-as codetermination does in Germany-to minimise agency costs between shareholders and employees - does not necessarily imply that it will be less problematic in terms of externalities. Corporate conduct that harms the environment but leads to corporate growth benefits both investors and employees.

What, then, are the implications for corporate governance? There are clearly lessons to be learned about the appropriate use of high powered incentives. However, the most striking implication would seem to be the need for effective personal liability for individuals who either deliberately engage in misconduct, or who fail to ensure the implementation of sufficient risk management. The former, which would be criminal liability, is already in place in most jurisdictions, but suffers from serious problems of proof. The latter, however, which would take the form of negligence based liability, could usefully be strengthened.

Where the probability of detection of misconduct is low, then personal liability for managers is an important way to counteract excessively high powered incentives. Such liability, where breaches of the law are concerned, suffers from none of the standard objections that motivate the business judgment rule in the US and other jurisdictions, including Germany. Decisions to break the law are not business decisions; decisions to engage in oversight to ensure that lawbreaking is not occurring within the firm, are not business decisions. They attract the duty of care. However, it should be clear that any such liability should have a reasonable chance of attracting ex post judicial scrutiny of managerial oversight, and that any such liability should not 
be insurable. The corporate laws of many jurisdictions do not yet go this far. Insurance is routine. In Germany and the UK, it is clear that liability would be available on a negligence standard, but the chances of a lawsuit being brought have been, at least so far, slim. In a case of oversight failure, this would normally be a problem that the board as a whole might be implicated for. This in turn implies a decision to litigate is unlikely, absent a change of control or a derivative action. The bars to derivative actions in Europe are still too high for these to amount to an effective deterrent. In Delaware, where shareholder litigation is much easier to launch, the duty of oversight is only ever framed in terms of good faith, and were it to go further, would be subject to routine waiver under DGCL $§ 102(b)(7)$.

Another possibility might be to contemplate public enforcement of directors' duties under these circumstances. This model is adopted in Australia, where ASIC has power to enforce directors' private law duties.

All this presupposes some guidance as to what sort of actions such oversight should involve. Here we move into the realm of 'risk management'. The VW case has some very interesting pointers about this too. The striking thing about the VW case is how the actions of a small number of technical personnel can lead to harms affecting 11 million vehicles. The deceit was perpetrated through software - through code. A modern premium car is a particularly complex piece of software, containing over 100 million lines of code-compare that to 50 million for the Large Hadron collider, or 60 million for all the code in Facebook. The more that the execution of corporate activity shifts from humans to software, the more the focus of risk management must be on those who design and authorise the code. In short, going forwards, the selection, training, compensation and oversight of programmers and software development should probably be a central feature of risk management, with respect to compliance with external obligations, in any industry.

Date of Publication: 18 May 2016 


\section{Douglass North and Brazil’s “Car Wash" Scandal}

\section{BRUNO MEYERHOF SALAMA}

Douglass North, winner of the 1993 Nobel Prize in economics, passed away late last year at the age of 95. North was noted for advancing the theory that institutions - which he referred to as a society's "rules of the game" - are critical for the functioning of the economy. His defence of the fortification of mechanisms for upholding contracts and property laws is now well known. Not as famous, however, is his equally insightful theory of the dynamics of institutional evolution in societies. This lesser known line of thinking allows us to engage in useful reflection about the current imbroglios gripping Brazil's bustling democracy.

North's reflections on institutional evolution hold "social order" as the foundational concept. Formulated late in his career, his considerations were consolidated in his last major book, Violence and Social Orders: A Conceptual Framework for Interpreting Recorded Human History, published in 2009 in co-authorship with Barry Weingast and John Wallis. In a country with a "limited access" social order, the political system manipulates the economic system so that elites can rent-seek and block access by non-elites to economic opportunity. In such countries, appearances can be deceiving. Formally speaking, there may be a tripartite distribution of power, professional state bureaucracies, and elections by private ballot. The restrictions to access, however, are largely informal, and arise because the dominant structure in society is personal interaction rather than impersonal laws. In these settings, stability is achieved through the collaboration and exchange of favours among the political elite and the economic plutocracy. Corruption small and large, both inside and outside bureaucracy, is pervasive. When everyone has an implicit glass ceiling, cooperation is better than competition.

By contrast, in a country with an "open access" social order the basic dynamics of wealth creation and the allocation of power are not based on exchange of favours, but on political opposition and the race to create innovations that generate economic progress. No group is able to impose its will over the others unilaterally, so a balance of political power prevents state appropriation by any one group. Even if each group constantly attempts to take control over the public sphere, none of them is strong enough to do so in a decisive manner. The groups monitor each other, and when conflict emerges the impasse is overcome not by exchanging new privileges within the elite but by creating new impersonal rules. Existing institutions and beliefs prevent the emergence of violence and create stability, paving the way for the consolidation of the rule of law.

This is where North's theory intersects with the striking facts that have now become public through the "Lava Jato" (literally, Car Wash) scandal and related investigations ongoing in Brazil. 
In 2014, in the course of an ordinary police investigation into money laundering through a chain of gas stations and laundries, the Federal Police came across evidence of multi-billion dollar corruption at the state-controlled oil giant, Petrobras. Evidence has emerged of a regimented scheme of institutionalised corruption and money laundering involving high-level politicians, Petrobras officers, and businessmen from some of Brazil's largest private companies who conspired for years to supply Petrobras with overpriced goods and services. The alleged kickbacks from Petrobras were used to finance political campaigns and to bribe government officials.

So far, more than 50 politicians have been implicated, including former President Lula da Silva, the president of the Brazilian Senate, the president of the Chamber of Deputies, and the treasurer of the ruling Workers' Party (PT). In the midst of an economic downturn, this corruption scandal has snowballed and paralysed the Brazilian political system, also blocking the (as yet timid) attempts by President Dilma Rousseff to address the country's growing budgetary deficit. Even if impeachment procedures recently initiated in Congress against President Rousseff eventually fail, social unrest and political fatigue strongly suggest that this fourth consecutive presidential term of office of the PT in power will be the last.

So a new party will come to power. What then? There are at least two possibilities. The first is pessimistic: everything will return to the way it has always been. Any eventual political changes will be cosmetic and limited, because in a country like Brazil, the more things change, the more they remain the same. Decades ago, dictatorship was to be blamed; now it is the election cycles. Thanks to the electoral cycles of reinstated democracy, there is an urgency to steal more, as election campaigns are expensive; and to steal more quickly, because the timeframe to fill the coffers is tighter. Everything is counterintuitive: greater risk of police detection and legal consequences will translate into bigger bribes, driving good men away from politics and instead attracting opportunists. Perhaps the result then in Brazil would be a repeat of the Italian Operation Clean Hands from some years back. In Italy, a whole political class was liquidated, but it seems that the rules of the game have not changed and everything has returned to the status quo. In short, nothing will improve for us in Brazil: our politics are doomed to be based on privilege; our society, on backwardness; our democracy, on illusion.

The alternative reading is more hopeful, and a Northian perspective helps understand why. Democracy-which is first and foremost a competition for power through votes - will work as intended. The road will be long, but a decisive step will have been taken if the race for power helps reduce, rather than expand, corruption. Despite the impositions of the electoral cycles and the need to finance election campaigns, crime typically does not pay when state organisations work tolerably well. Those in power today will no longer be there tomorrow, so they must take heed and walk straight and narrow-not for fear of political persecution but out of fear of the application of the rule of law. Therefore, the logic goes, the risks of legal action and punishment will gradually render the practice of corruption not only immoral (which it has always been), but also contrary to the self-interest of those in power. If this were to occur, the political culture would change, and then, perhaps with some luck, it would be possible to rein in populism and reform the Republic step by step, re-setting the existing rules based on a spirit of dialogue, compromise and a vision of a more prosperous future. 
North recognised that institutional changes do not necessarily come quickly, may not be successful, and are subject to setbacks of all kinds. But if there is a possible optimistic reading amid the current havoc in Brazil, it is that operations such as Car Wash are part of a process of institutional advancement and a growing openness of the social order. If all goes well, then the current political impasse, rising unemployment, brutal economic recession and increasing poverty will in the future be recast as the bitter price that Brazilian society had to pay in its path toward the establishment of the rule of law. To be sure, no society can be reformed only by police action, and whether the desired institutional improvements will in fact ensue from the current scandal is yet unclear. But in a country with as much potential as Brazil there is a lot to be gained by implementing reforms that will pave the way for prosperity. The size of our challenges suggests caution, but at this point a little hope might do us Brazilians good.

Date of Publication: 21 March 2016 


\title{
The Rise of the Machines - How Automated Digital Assistants Can Reduce Competition (and the Cash in Your Wallet)
}

\author{
ARIEL EZRACHI \& MAURICE STUCKE
}

Who wouldn't want a personal digital butler? Many of us already benefit from basic digital assistants such as Google Assistant, Apple's Siri, Facebook's M, and Amazon.com's Alexa. The future heralds faster, smarter and more human-like versions that can transform the way we access information (in suggesting restaurants, news stories, hotels, and shopping sites) and communicate. But as we welcome these intelligent, voice-activated helpers to our homes, we may not recognize their toll on our well-being.

As we shift from a mobile-dominated world to an AI-dominated platform, our digital butler will increasingly control our mundane household tasks, like regulating room temperature, adjusting our water heater and playing our favourite music. It will be harder to turn our butler off. Moreover, it will be tempting to increasingly rely on the butler for other activities, such as the news we receive, the shows we watch, and the things we buy. The more we communicate primarily with our personal assistant, the less likely we will independently search the web, read independent customer reviews, use multiple price-comparison websites, and rely on other tools. We will entrust our butler to undertake this effort and report its results. In relying on our butler, we become less aware of outside options.

That increase reliance on the digital assistant (and provider's online platform) is the Holy Grail for the super-platforms, which provide us with the digital butlers. Their aim is to increase the time we spend on their platform and to control as many aspects of our online interface.

Take, for example, the Google assistant, which forms part of the company's 'effort to further entrench itself in users' daily lives by answering users' queries directly rather than pointing them to other sources.' Likewise, Facebook, through its digital assistant - M - seeks to replace most of our web searches and apps with a function within Facebook Messenger. As our personal assistant becomes our default, so too will its operating platform's applications and functions.

Thus the intent is for the digital butler (and the platform on which it operates) to become our key gateway to the World Wide Web. But in controlling this interface and accessing our communications and data, the gatekeeper could also abuse its significant market power.

For instance, the digital butler may help the platform refine its profile about us, including our likely reservation price, use of outside options, shopping habits, general interests, and 
weaknesses (including moments when our willpower is fatigued). This information can enable 'behavioural discrimination', where the platform can facilitate our buying products that we otherwise wouldn't, at prices closer to our reservation price. The more we rely on the butler, the less likely we will be aware of this discrimination. Even if we search the web, the ads, products, or search results we see may be orchestrated by our butler.

While providing us with a distorted view of available options and market reality, our trusted butler can also exclude rivals. When the butler promotes its affiliated products and services, it may become harder and costlier for retailers unaffiliated with the platform's advertising business to reach us. Even when the retailer can gain our attention, the personal assistant may interject with its own recommendation, suggesting a special deal by a member of its platform's ecosystem. In this multisided market, the assistant may subtly push certain products and services and degrade or conceal others, all in the name of personalization.

Rather than deter such abuses, market forces, given the data-driven network effects, can actually increase entry barriers. The strong platforms (and their butlers) become even stronger, extracting even more personal data, and commanding even higher rents to allow others to target us. Not only will our pocketbooks be affected. Our political and social discourse could also be manipulated, as we increasingly rely on our butler for our news and entertainment. The gatekeeper could subtly, but effectively, intellectually capture its users in this unique bubble - where users happily roam, unaware of the outside market for products, services and ideas.

For a more detailed discussion, see our new book 'Virtual Competition: The Promise and Perils of the Algorithm-Driven Economy'.

Date of Publication: 5 October 2016 


\section{Smart Contracts: Bridging the Gap Between Expectation and Reality}

\section{CHENG LIM, CALUM SARGEANT, \& TJ SAW}

There has been an explosion of interest in 'smart contracts' and blockchain technology over the past two years, with software developers, financial institutions, regulators, and law firms rushing in to explore smart contract design and blockchain development. The hype over smart contracts has resulted in headlines such as 'Blockchain "smart contracts" to disrupt lawyers', and speculation that blockchain smart contract technology 'threatens thousands of legal jobs and lawyers' role in intermediating commercial negotiations and disputes'.

Advocates of the technology are excited by the potential for smart contracts to encode and perform complex agreements automatically. The dream is to build a contract from a code library which will be stored on a blockchain, signed digitally and which will set in motion an irrevocable set of instructions that will be automatically executed, subject to clearly pre-defined exceptions. To commercial parties, the appeal of smart contracts lie in (i) the digitisation of trust through certainty of execution, and in (ii) the creation of efficiency through the removal of intermediaries and the costs they bring to transactions.

There is little doubt that smart contracts will find compelling use cases and achieve those objectives in many instances. But equally, it is important to realise the limitations of smart contracts and understand that there are many elements of contractual relations that are not suitable for performance through deterministic computer logic embodied in a smart contract. If there are unrealistic expectations for what the technology can achieve, early adopters may find that they frustrate, rather than simplify, their dealings with others.

We set out in this article to define an appropriate role for smart contracts (whether on a public or consortium blockchain), and to provide a model for designing smart contracts which can operate effectively and safely in a world which is full of uncertainty, ambiguity and that is not deterministic.

\section{A smart contract is not everything}

The term 'smart contract' is a misnomer. A smart contract shares theoretical similarities with a legal contract, in the sense that they are both frameworks for regulating the interaction between different entities, but it is important to note where those similarities start and end.

A smart contact is, at its heart, a computer programme - encoded logic that receives certain inputs and executes a set of instructions to reach one of many pre-defined outcomes. It is not 
relevant to the encoded logic whether or not promises or consideration exist between the parties, or whether or not representations have been made in relation to the subject matter of the instructions. It is not relevant whether its instructions were intended or legal. At its heart, a smart contract simply guarantees execution of a particular code base.

A normal, non-smart, or 'dumb' contract, on the other hand, is an agreement between two or more parties characterised by mutual promises or obligations, and is enforceable by law. A dumb contract can be thought of as serving multiple and possibly interlocking goals:

- setting a database of obligations - a contract serves as a catalogue of the mutual obligations and promises between two or more parties. It is a collection of negotiated points relating to a particular agreement between the parties, stated in language that parties can refer to and at least in theory understand. Even so, there are many situations in which courts have to determine what the parties agreed, or intended to agree, in their contract, which has led to rules of law such as the parol evidence rule, and the implication of terms into contracts which are 'so obvious, that they go without saying';

- regulating the relationship between contracting parties - a contract is given legal effect by the surrounding framework of laws in which the contract sits, thus ensuring that parties are held to their obligations. The legal framework elevates an agreement from a moral obligation to an obligation that is recognised and enforced by society at large. The law of the relevant jurisdiction may compel performance of the obligation (as in the case of an order for specific performance or injunction) and may incentivise performance by penalising breach. Alternatively, the external legal framework may allow for a modification of the obligations in the contract if, for example, there is a need to imply an additional term into the contract. And of course, the legal framework may allow the contract to be completely voided if, for example, there is illegality or a total failure of consideration; and

- providing part of the execution mechanism - a contract may also contain elements of a mechanism by which contractual obligations can be executed. Wrapping an obligation in the cloak of contract creates an expectation of performance supported by the external legal framework, giving rise to an 'execution norm'. The prospect of legal enforcement that attaches to a contract, as opposed to a moral obligation, increases confidence that the obligation will be performed.

\section{How does a smart contract compare to a dumb contract?}

While a smart contract may contain some part of the 'database of obligations' between the parties in its instructions, it is unlikely to be a comprehensive catalogue of all those obligations, particularly where the contractual obligations are complex. This is because:

- parties may negotiate terms that are not capable of being assessed deterministically by a computer program (that is, not capable of Boolean expression and an algorithmic determination, but instead requiring human judgement); 
- in order to be sufficiently expressive, obligations may import indeterminate concepts of reasonableness or appropriateness that again are not suited to algorithmic determination;

- the expression of an obligation in code may not accurately reflect the agreement between the parties (for example because of error or omission); and

- the contract may itself contain a further agreement to agree, or a mechanism for amending the contract which is not in itself algorithmically deterministic.

Of course, a smart contract is clearly part of the execution mechanism. In fact, it is possible for the smart contract to be the entire execution mechanism, and not just an element of it. The execution norm established by a dumb contract could be replaced by the execution norm of irrevocable instructions of a smart contract that guarantees performance. This 'guaranteed execution' of encoded obligations is the key feature of a blockchain smart contract.

Smart contracts operate without reference to any external legal framework, in that execution or performance of the obligations in the smart contract happens independently of the surrounding legal framework. However, this does not prevent that legal framework from applying to and affecting the broader contractual relationship between the parties. It is possible that the law may mandate an outcome which is different to that which is programmed into the smart contract, for example in order to correct a misrepresentation which is embodied in the code of the smart contract.

In other words, smart contracts do not exist in a vacuum. Leaving aside the inability of smart contracts to document obligations which are not algorithmically deterministic, those who wish to use or establish smart contracts will have to deal with issues which have existed for many years in the 'dumb' world. These are issues such as:

- What if the code base does not reflect what the parties understood to be their agreement (eg a common mistake of law or fact)?

- What if the effect of the code base was represented by a party to be different to what it actually was (eg a misrepresentation)?

- What if one party did not have the legal capacity to enter into the smart contract (eg being under age)?

\section{Particular challenges with public blockchain smart contracts}

One particular new issue is the design of smart contracts which sit on a public blockchain and which interact with different and possibly hostile actors with misaligned incentives. These smart contracts need not only to deal with the challenges referred to above, but to also incorporate principles of defensive programming as well as analysis of the underlying game theoretic design.

In particular, it is imperative for a public smart contract to:

- have its scripting language compile properly into its machine language, in the way it was intended; 
- be structured in a way which is computationally efficient (making use of the fewest state changes to achieve the desired outcome) as it is expensive to devote computational resources over the blockchain to run a program; and

- be robust in its design so that malicious actors may not exploit weaknesses in the code to 'stalk' or 'spam' the contract and prevent its legitimate intended uses from being executed.

This is more than a theoretical possibility, as illustrated by the recent events surrounding the smart contracting public blockchain network Ethereum and the Distributed Autonomous Organisation (DAO) smart contract that sat on it. The DAO was a smart contract intended to pool investment funds (which, at one point, totalled $\$ 150 \mathrm{M}$ worth of the cryptocurrency 'Ether') which could be allocated by members of the DAO to different projects. A hacker spotted a mistake in the programming of the smart contract, and utilised it to drain the Ether from the DAO into child DAOs controlled by the hacker. Importantly, the underlying Ethereum blockchain and smart contract both functioned in the pre-determined way in which they were designed, but the failure of proper smart contract design created a functional vulnerability which ultimately undermined the intent of the DAO.

\section{A model for designing smart contracts}

We start from the proposition that a contract is not a set of irrevocable instructions but rather a collection of mutual obligations subject to the overlay of law. A smart contract is a set of instructions that may give effect to the obligations of the parties, but it must also be amenable to rectification where it no longer satisfies the requirements of law or fails to reflect the obligations agreed by the contracting parties. Where a smart contract is designed in a way that cannot achieve this, it may result in misalignment between rights recognised by law and rights recognised by the public.

Looked at in this light, a smart contract is really best suited as an execution mechanism for a set of deterministic obligations, rather than as a contract in itself. In some ways, it is similar to an 'escrow' mechanism which is common in M\&A transactions, where money is paid to a trusted third party stakeholder, and which can be released to one or the other party in certain specific, determined circumstances. The smart contract is part of the contractual matrix between the parties and is the mechanism by which execution of certain obligations is guaranteed.

We consider the following to be an appropriate model for designing and implementing 'smart contracts':

- there should be a dumb contract between the parties, in the form of a 'legal wrapper' which sets out terms of the contract which are not deterministic and not suitable for execution through the smart contract. An example of this would be a right to terminate a contract or take a particular action because of the occurrence of a 'material adverse event';

- the smart contract code must be designed to execute elements of the contract suited to algorithmic determination, for example an obligation to pay an amount of money at a fixed time, or a process for determining an interest rate by reference to a margin and a particular published reference rate such as LIBOR; 
- the legal wrapper should incorporate the smart contract code by reference into the contract, but the dumb contract should take priority over the code if there was some conflict between the two;

- there should be a 'fail-safe' in the smart contract code that allows the code to be terminated in certain agreed scenarios by any party to the contract (eg, by trusted authorities with multi-signatory keys). Consequences of the use of the 'fail-safe' (whether appropriate or not) would be resolved by the parties in accordance with the legal wrapper and within the framework of the law. The 'fail-safe' could also allow parties to amend the smart contract code when there is a contract variation, or where a party chooses to waive certain rights under the contract.

We posit that smart contracts are unlikely to make lawyers extinct. In fact, lawyers are going to be just as important for society moving forward to make sure that smart contracts, like dumb contracts, reflect the intention of the parties, and allow for the execution of agreed outcomes.

Date of Publication: 11 July 2016 


\section{Brexit to the European Economic Area: What Would It Mean?}

\section{JOHN ARMOUR}

As the dust clears from the result of the UK's referendum on EU membership, new Prime Minister Theresa May and her team must begin serious consideration of the options open to the UK. Two issues are likely to sit at the heart of the UK's negotiation.

First, there is an economic imperative to preserve the operation of the financial services sector. UK-authorised financial firms currently enjoy a 'passport' to operate throughout the EU without additional authorisation. Loss of the EU 'passport' would damage not only intra-EU financial services exports, but also reduce the willingness of third country (especially US) firms to base European operations in the UK. According to TheCityUK, financial and related professional services account for $7 \%$ of domestic employment (two-thirds of whom work outside London), $12 \%$ of UK GDP and $12 \%$ of UK tax revenues. The EU is the largest export market for UK financial services. Its loss could be an economic disaster for the UK.

Second, in light of the significance attached to concerns about immigration in the referendum campaigning, there is a political imperative to secure a change to the terms on which immigrants are able to enter the UK. These two desiderata are widely thought to be incompatible: EU officials and senior politicians in other Member States have publicly opined that the EU's framework is not available a la carte: we must take free movement or leave financial services. What, then, are the options for the UK?

To date, consideration of alternatives to the EU has revolved around three possibilities popularly known as the 'Norway', 'Swiss' and 'Canada' models. The so-called 'Norway model' would involve re-joining the European Free Trade Association (EFTA) and becoming a party to the European Economic Area (EEA). Ironically, EFTA membership would be a round-trip for the UK, which was the prime mover behind the establishment of EFTA in 1960 as an economicallyoriented framework for trade liberalisation between European countries, in contrast to the EEC's more politically-oriented approach. Yet over the years, EFTA increasingly became seen as a 'waiting room' for EU membership, from which most of its original member states subsequently graduated. Today there are just four EFTA members: Iceland, Liechtenstein, Norway, and Switzerland.

A key difference from the EU is that EFTA is not a customs union. This means that, while EFTA members agree to waive tariffs on goods and services amongst themselves, they do not agree a common policy in relation to trade with third countries. This would open the possibility, 
for example, to more favourable trade terms with Commonwealth countries, as was the case prior to the UK's accession to the EEC in 1973. Nevertheless, EFTA does negotiate shared free trade agreements with third countries on behalf of its members, which the UK would be free to join or not as it wished.

The most important such agreement is the 1994 European Economic Area ('EEA') Agreement, which governs relations between three EFTA members (Switzerland opted out) and the EU. The EEA entails acceptance of the EU's four freedoms: goods, persons, services and capital. Moreover, the EEA requires contracting parties to implement as part of their 'internal legal order' the vast majority of the EU's acquis (as set out in the 22 Annexes to the EEA Agreement), save for the Common Agricultural Policy, the Customs Union, the Common Trade Policy, the Common Foreign and Security Policy, Justice and Home Affairs, and the European Monetary Union.

As regards financial services, the EEA-relevant EU measures include those pertaining to company law and financial services. As a result, were the UK to become a party to the EEA, UKauthorised financial services firms would keep their 'passport' to market products and services throughout the EU. Moreover, UK-registered companies founded by entrepreneurs in other EU member states (of which there may be upwards of 100,000) would continue to have their existence recognised by other EU jurisdictions.

However, there are two significant drawbacks to an EEA version of the 'passport', as opposed to the EU version. First, the UK would no longer get any say over the content of the rules. As a member of the EU, the UK has been a highly influential participant in the legislative process. In particular, the EU's early $21^{\text {st }}$ century reforms on securities markets owed much to UK thinking, and the UK has been a vocal opponent of some post-crisis measures it views as overkill.

Second, the 'transplantation' of EU legislation into the laws of EEA members is not automatic; rather, members must each consent to enact it into their domestic laws. This can lead to a lag between the enactment of EU laws and their EEA adoption. There have been particular problems with post-crisis EU financial regulation. The new European System of Financial Supervision ('ESFS'), introduced in 2010, established EU-level agencies with delegated authority to write binding rules. Implementing this creates constitutional difficulties for some EEA members, and although the matter is a priority for the EFTA Standing Committee, it has not yet been resolved. Because the ESFS is embedded in all subsequent financial services regulations produced by the EU, virtually none of the EU's post-crisis financial regulation is yet applicable in non-EU EEA signatories. Indeed, the majority of the EU legislation in the 'holding pattern' status of 'identified as EEA-relevant but not yet adopted' consists of financial services measures.

Financial services regulation in the EU has moved quickly since the financial crisis. If UK firms have no say in the direction of that process, and cannot be guaranteed the application of the latest measures, then the current EEA model will not be suitable for the fast-changing regulatory challenges of the financial sector. This means that if the UK seeks to sign up to the EEA, it would need to ensure at least some mechanism to improve implementation speed for financial services measures and ideally some process for securing UK input to the rules. This would be in both sides' 
interests, because regardless of EU membership, their financial sectors will continue to be interwoven as a practical matter, posing a mutual source of potential systemic risk.

The EEA therefore does not look a promising avenue for the UK. Straightforwardly applied, it would involve no additional immigration control and a greatly enfeebled version of the financial services passport. Of course, the UK might try to negotiate exceptions to the EEA's free movement parameters: Liechtenstein, for example, obtained a five-year transitional period. However, the UK's prospects for such an 'EEA minus' deal seem distinctly unpromising, given the risk to the EU of setting a precedent that other member states might follow. More concerning for the UK is the risk that other EU member states, jealous of London's success in financial services, might offer an 'EEA minus' version that permitted the UK to opt out of free movement but tore up the passport for financial services.

What, then, of the other options? The 'Swiss' and 'Canadian' models each refer to bilateral agreements between these countries and the EU, which could provide templates for a bilateral UKEU deal. The bundle of bilateral measures between Switzerland and the EU cover free trade in goods, but not services, and also require Switzerland to accept the free movement of EU citizens. This configuration would clearly be unappealing to UK voters, as indeed it now appears to be to the Swiss. In contrast, the recently-negotiated Comprehensive Economic and Trade Agreement ('CETA') between Canada and the EU, encompasses not only goods but a wide range of services, and does not entail any commitment on Canada's part to free movement of persons. However, its provisions on financial services (Chapter 13) do not extend anywhere near the 'passport' recognition enjoyed by firms authorised within the EU. Brexit optimists might argue that the UK might be in a stronger negotiating position even than Canada and so able to achieve an even better result. Yet it should be remembered that CETA has taken seven years to negotiate, that any bespoke agreement with the UK would be at least as complex, and that EU member states would have concerns about precedent-setting which would not have applied to Canada. Uncertainty blights investment, and uncertainty of the extent and duration entailed by such a negotiation could easily be fatal for much of the UK's financial services sector.

Date of Publication: 19 July 2016 


\section{Brexit Negotiation Games}

\section{HORST EIDENMÜLLER}

The UK has voted by a slim majority to leave the European Union. How is this going to happen? What will be the negotiation strategy of the UK, on the one hand, and the European Union, on the other hand? The ensuing 'Brexit Negotiation Games' will be heavily influenced by Article 50 of the Treaty on European Union (TEU). This provision sets out the legal process for withdrawal from the Union. The process is initiated by a Member State's notification to the European Council of its intention to withdraw (Art 50(2)). Following such notification, a 'withdrawal agreement' shall be negotiated between the Council (of the European Union) and the respective Member State. The agreement shall also set out the future relationship of that State with the Union. It shall be concluded on behalf of the Union by the Council, acting by a qualified majority, after obtaining the consent of the European Parliament. 'The Treaties [TEU and TFEU] shall cease to apply to the State in question from the date of entry into force of the withdrawal agreement or, failing that, two years after the notification referred to in [Art 50(2)], unless the European Council, in agreement with the Member State concerned, unanimously decides to extend this period' (Art 50(3)). For the purposes of these provisions, the UK shall not participate in the discussions of the European Council or Council representing it or in decisions concerning it (Art 50(4)). A qualified majority shall be defined in accordance with Art 238(3)(b) TFEU. Such majority requires at least $72 \%$ of the members of the Council representing the participating Member States, comprising at least $65 \%$ of the population of these States. At least $72 \%$ of 27 Member States (without the UK) means at least 19 Member States. Germany's population comprises $18.30 \%$, France's 14.97\%, Italy's 13.70\%, Spain's 10.47\%, and Poland's $8.57 \%$ of these 27 Member States. No agreement can be concluded against the vote of Germany and France and any one of these three other Member States acting together.

What is the interest of the UK, and what might be its negotiation strategy against this background? The referendum vote is not the legal declaration required by Art 50(2) TEU. It is a political mandate to issue that declaration and negotiate a Brexit agreement. Assuming that the UK government in fact plans to follow this mandate, it would be prudent to wait some time before formally initiating the process. The UK might even attempt to negotiate a Brexit agreement in the shadow of a non-declared wish to exit and issue that declaration only once the agreement has been finalized. It would be prudent to wait some time before issuing the Art 50(2) declaration because, for domestic political reasons, a new government under a new leadership should be negotiating Brexit given that the current one has favoured remain, and it takes some time to accomplish a cabinet reshuffle and sort out the domestic political upheaval. It might be considered clever to postpone the formal exit request as long as possible given that this declaration triggers the twoyear negotiation period. The UK clearly has an interest to negotiate Brexit on the most favourable terms, i.e. to conclude an agreement that secures as many benefits of the internal market for the 
UK as possible while minimising the costs associated with this. However, if it formally declares its wish to leave and no such agreement can be negotiated and agreed (which will be difficult), it will be out without an agreement - the worst possible outcome. Hence, it does not come as a surprise that Mr Cameron has announced that he will not resign immediately but only in October and that the Brexit negotiations will need to be led by his successor.

At first sight, it appears that the Union cannot force the UK to issue the formal exit declaration required by Art 50(2) for the start of the Brexit negotiations. The Union appears powerless. But the UK cannot force the Union to negotiate in the shadow of a non-declared desire to exit either, and the Union has made already clear that it is not going to do this. What is more, any Brexit agreement will need the consent of the European Parliament and a qualified majority in the Council. A qualified majority in the Council against the vote of Germany and France realistically cannot be obtained. So the UK faces the prospect of Brexit without an agreement if it antagonises the larger remaining Member States and/or the European Parliament. In fact, on 25 June, the foreign ministers of the six founding Member States of the Union pressured the UK to formally initiate the process speedily, and on 26 June Mr Schulz, the president of the European Parliament, called upon Mr Cameron to do so on occasion of the next Council meeting on 28 June. Further, on 27 June, the German chancellor Ms Merkel is meeting with Mr Hollande and Mr Renzi, representing the most simple 'blocking coalition' for any deal negotiated with the UK. If these three leaders prompt the UK to come forward with an exit declaration in the near future, they are sending a strong strategic signal: if you wait until October or even longer, you should not hope to convince us of a withdrawal agreement that is favourable to you.

Hence, it appears that the UK finds itself in a precarious position. Mr Cameron might have once more overplayed his hand in suggesting that the Article 50(2) declaration can and will wait. On the other hand, the political turmoil in the UK is significant enough already. What will happen to the country if indeed Mr Cameron reverses his decision and comes forward with the declaration soon, possibly already on the next Council meeting on 28 June? All the bargaining leverage is on the Union's side, and it does not seem like the Brexit negotiations will leave room for a lot of potential cherry-picking on the UK's part.

The strategic picture is complicated by the fact that the interests of the remaining Member States are not homogenous. Export-oriented countries such as Germany that have more to lose from the UK being cut off the internal market have an interest in concluding a withdrawal agreement that gives the UK and themselves a 'good deal'. However, it is difficult to see how such cherry-picking can be accomplished. Surely any deal will be scrutinised in detail by all interested parties. Giving the UK a special deal is almost impossible without setting undesirable incentives for other Member States to free ride on any such deal. And while Germany, France and other larger Member States may be able to block any deal that is not in their interests, they cannot force a deal tailored to their interests on the other Member States. Remember that $65 \%$ in terms of the population is the required majority. Everybody knows this, and ex ante this works as a commitment strategy that again weakens the UK bargaining position: the Union will not cut a deal that is not acceptable to a broad majority of the remaining Member States. And if there is no deal, there is exit without a deal. 
Finally, the ensuing negotiations are interesting also because they are going to involve agents. The Union already has announced that its negotiation team will be led by a Belgian diplomat, Mr Seeuws. Mr Seeuws was chief-of-staff to Mr Van Rompuy, Mr Tusk's predecessor as chairman of EU summits, until 2014. He is an experienced negotiator and also a strong advocate of deeper EU integration. This sends a clear signal to the UK also with respect to what sort of 'withdrawal agreement' to expect: not one that weakens the Union, e.g. by cherry-picking elements. Even more important, Mr Seeuws does not represent one of the large Member States with more economic and political power. This gives Germany and France in particular more flexibility in the negotiations and is less prone to being viewed as an expression of 'bully politics' than if, like in the Greek bailout negotiations, it would have been Ms Merkel or Mr Schäuble, the German Finance Minister, who had been designated as the lead negotiator.

I think it is fair to say that the Brexit vote is seen by a majority of non-British citizens as being bad for Europe, but bad for the UK in particular. Right now, it appears that the negotiation table is not laid out such that the dire consequences of the vote could be much improved for the UK. Simply put, the rules of the 'exit game' put the UK in a very weak bargaining position: if a 'withdrawal agreement' is not backed by a broad majority of the remaining Member States, the UK faces Brexit 'pure and simple'. It will find itself outside of the Union with the right to apply for re-entry according to Article 49 (Art 50(5)). It will be in a club with Turkey.

Date of Publication: 27 June 2016 


\section{A New Referendum is a Constitutional Requirement}

\section{PAVLOS ELEFTHERIADIS}

The most recent primary legislation on the relations between the European Union and the United Kingdom is the European Union Act 2011. This Act, who some scholars called at the time an 'unprecedented constitutional experiment' is known for the fact that it establishes a very unusual 'referendum lock' before an amendment of the EU Treaties can be ratified by the UK. It introduces a rule that all serious amendments of the EU treaties will have to be approved both by an Act of Parliament and by the electorate in a referendum. The intention behind that Act was to make sure that the UK had thought long and hard before participating in further EU integration. The Act was seen as controversial among lawyers, because it changed the 'manner and form' in which the sovereignty of parliament is exercised.

In my view, the Act adds an important dimension to the debate about the effects of the EU referendum of June 23. The 2011 Act has been written in such an expansive way as to encompass, in my view, not only treaties that amend the EU treaties, but also treaties that the UK is due to enter as a result of withdrawing from it. This may be a surprising suggestion, because the drafters of the 2011 Act probably had not thought about this prospect. Nevertheless, the Act is to be applied on the basis of what it says, not on the basis of what its drafters were thinking at the time. On the basis of the words on the page, a new referendum is most likely legally necessary before the UK withdraws from the EU.

The argument is simple. The 2011 Act provides at section 2(1) that it applies to a 'treaty which amends or replaces' the EU treaties. Treaties that 'amend' the EU treaties affect, of course, only members of the EU. The treaty between the EU and the withdrawing UK will not amend the main treaties, namely the TEU and the TFEU (a separate treaty among the remaining 27 will have to do that). But, as we saw, the Act, in its attempt to include perhaps everything about the EU, covers also those treaties that 'replace' the EU treaties. What does 'replace' mean? 'Replacing' is something different from 'amending'. Because it is different, it must be something different from the ordinary amendment of the current EU treaties. It is therefore obvious that a new treaty between the withdrawing UK and the remaining EU could be one 'replacing' the European treaties, at least as far as the UK is concerned. It is a treaty that replaces the UK's rights and obligations towards the EU.

This conclusion is strengthened by the fact that the Act defines (in section 1(4)) part of what it means by 'amends'. There is no definition at all, however, of what is meant by 'replaces', 
which is left entirely open. It is therefore clearly plausible that both a withdrawal agreement that the UK will agree with the EU under Article 50 (the 'withdrawal agreement') and an in principle separate (and hopefully contemporaneous) future trade relations agreement ('the trade agreement') will be treaties that 'replace' the EU treaties as far as the UK is concerned. This is because all the rights and duties of the UK towards the EU would be replaced by the rights and duties created by the withdrawal agreement and the trade agreement. If this is the case, then both these agreements will fall under the scope of the 2011 Act.

Not all agreements require a referendum according to the 2011 Act. Section 4 of the Act outlines a list of cases where a new treaty that in principle falls under the scope of the Act 'attracts a referendum'. If any one of the conditions mentioned there is met, a referendum is required. These conditions are very broad, perhaps excessively so. It is likely that those who drafted them did not have in mind a treaty that is part of a process of withdrawal from the EU. Most likely, they had in mind its opposite, a treaty bringing further integration. But the words mean what they say. Any court will have to give effect to them as they are in the statute book.

This was clearly the intention of the government at the time. Introducing the Second Reading of the Bill for this Act in the House of Lords Lord Howell of Guildford (who was then Minister of State, Foreign and Commonwealth Office) said about section 4: "The Government make no apology for the complexity of the provisions. We want to make it clear for Parliament, the British people and, indeed, our EU partners and the EU as a whole where a referendum would be required under the Bill. We feel that a short, vague statement would leave any future decisions more open to challenge in Parliament and the courts'. So every one of these detailed provisions was carefully thought out.

The most obviously relevant cases seem to me to be in paragraphs $4(1)(\mathrm{i})$ and $4(1)(\mathrm{j})$, although others may also prove relevant:

(i) the conferring on an EU institution or body of power to impose a requirement or obligation on the United Kingdom, or the removal of any limitation on any such power of an institution or body;

(j) the conferring on an EU institution or body of new or extended power to impose sanctions on the United Kingdom.

The conditions do not refer to the balance of power or any arrangement of reciprocity. They are triggered if an EU institution or body is given the power to impose a single 'requirement' or 'obligation' on the UK, or if any limitation on existing powers is removed. They are also met if an EU institution or body is given the power to impose 'sanctions' on the UK.

Whether these tests of section 4 will be met by a future UK/EU treaty on withdrawal and future access to the single market depends on what those treaties will say. But it is in my view highly likely that at least one of these very broad tests will be met by any treaty creating reciprocal obligations in the process of withdrawing from the EU and establishing a future trading deal. For example, a withdrawal agreement will certainly impose obligations on the UK regarding EU citizens currently in the UK. This is especially so if the UK decides to replace its membership in the EU with membership of the EEA. As is well understood by now, being a member of the EEA 
involves accepting the rules of the single market without voting for them at the Council. So the test of section 4(i) will be met in both its limbs, because by virtue of the EEA agreement EU institutions will have been conferred a new power to impose requirements on the UK, while the UK will have lost both its power to vote in the Council and its right to bring an action to the Court of Justice against an institution of the EU regarding these obligations.

For different reasons, the tests of section 4 (i) and (j) may also be met by a bilateral treaty or set of bilateral treaties between the UK and the EU (the 'Swiss' model). First, among other things, any such agreements will most likely remove the protection that the UK currently enjoys not to be discriminated against by virtue of 18 TFEU. The agreement will thus remove a 'limitation' on the powers of EU institutions. Second, any new treaties will almost certainly create powers in bodies or institutions of the EU to impose a requirement or obligation on the UK (paragraph i) or even create some form of sanctions (paragraph $\mathrm{j}$ ) as in the WTO model of judicial panels, or by way of arbitration.

They will do so, most likely, in international and not in EU law, but the Act does not draw such a distinction. It says, for example, that what matters is the conferring of 'power' not 'power in EU law'. And if this applies to the set of bilateral treaties, it is also likely to apply to the WTO option as well.

Of course I am only summarising here issues that will require full and detailed consideration, if and when these treaties take shape. But the literal reading of the 2011 Act suggests that the tests are wide-ranging and therefore the threshold for meeting them is low. And, if any one of the tests of s.4 is met, a new referendum will be required by law. In short, because the scope of the 2011 Act is so wide and because it requires a referendum practically whenever there is any change in the allocation of powers in the relation between the EU and the UK, by changing these powers in the process of withdrawal, a new treaty or treaties between the withdrawing UK and the remaining EU will almost certainly meet some of the tests of the 2011 Act. This was not perhaps the intention of the drafters, but this will not matter (under the well-established Pepper v Hart criteria) where the meaning of a provision is clear.

If this argument - or a version of it - is correct, then it follows that practically any new agreement with the EU as a result of the EU referendum will have to be approved by a new referendum. Of course, the current government - if it could secure a majority in Parliament - could seek to enact new legislation to abolish the 2011 Act (or perhaps try to ignore it, relying on a rival account of parliamentary sovereignty). This is a feature of the omnipotence of our Parliament. But the retrospective change of the law will be seen as obviously self-serving, and as something offensive to the rule of law. The current government had a chance to address these issues when it secured the enactment of the European Union Referendum Act 2015. The terms of the referendum were set then by the current parliamentary majority. To retrospectively change these terms after the referendum has taken place in order to circumvent the legal obligation of a second referendum, will be rightly seen as constitutionally inappropriate. When the referendum was called, the obligation to hold a second referendum was already in the statute book. 
I conclude that a proposed new treaty between the UK and the EU that seeks to replace EU membership with a set of new trade agreements will most likely have to be approved by way of a new referendum according to the framework created by the 2011 Act. The only secure way to avoid such a referendum is not to enter into any new treaty with the EU at all. This would entail that the UK would leave unilaterally, without regard for future trade and in very bad terms. This, however, is an unthinkable scenario, one to bring certain economic disaster for the UK and one that has not been contemplated by the leave campaign or the government.

So what would a new referendum decide? The question would be about the proposed new treaty or set of treaties with the EU, which would have been agreed after a lengthy and probably laborious process as the best possible deal available to the UK. If the answer to this referendum is affirmative to the new treaty, then the new agreement replacing membership of the EU with another type of relationship will have been approved and will take effect. But if the answer is 'no' to the new agreement, then the status quo, namely continuing membership of the EU, will have received a renewed mandate by the electorate as a preferable state of affairs to the best available alternative. The electorate would have chosen to remain. At that point the government would have to revoke the Article 50 notification and the UK would continue being a member of the EU.

Date of Publication: 4 July 2016 


\section{How Brexit will Fail}

\section{PAVLOS ELEFTHERIADIS}

If Brexit fails, it will do so because withdrawal happens suddenly and with no indication about the future arrangements that will replace membership in the EU. In this short note, I explain how this process is likely to unfold. It may still succeed. It may be that, as the current United Kingdom government hopes, Britain will become a leading trading nation outside the European Union, without political and social friction and without going through a painful economic downturn.

For Brexit to succeed, we need a period of transition to the new trade environment. A smooth withdrawal from the EU should allow time for the UK to negotiate protection for London and for financial and related services (which may in the end prove unachievable), to secure the unfettered access of some key industries (eg car manufacturing) to the single market and for deals to be struck with the rest of the world (see for example the informative statement from the City of London Corporation). Special negotiations will be needed to clarify the position in Scotland and Northern Ireland. In any event, all relevant businesses, workers and organisations should know well in advance if they are to lose their EU rights and prepare for change. The problem is that there is no time for any of these things to be achieved.

A great deal of the legal commentary so far has focused on the power of the Government to give notification of withdrawal. The process, regulated by Article 50 of the TEU, envisages that a withdrawal agreement ought to be concluded within two year from that notification. If it is not, and if the member states do not, unanimously, decide to extend that period, then the UK will be automatically out of the EU. The question whether the notification needs parliamentary approval or not was heard at a three-day hearing at the High Court a few days ago. A decision is currently imminent.

Nevertheless, this discussion has obscured another more important point. Withdrawal, with an agreement or without, is only one piece of the puzzle. It is not the most important. The key to Brexit is the agreement between the UK and the EU after withdrawal, setting out their future trade relations. This 'trade agreement' will determine if London banks can do business in the EU, whether British cars will be subject to customs formalities and tariffs, or whether persons will need visas to travel and work in Europe. Such issues will not be resolved by the withdrawal agreement envisaged by Article 50. The trade agreement is a separate agreement to the withdrawal agreement. It is made by a different process and has different content.

The trade agreement, for example, requires unanimity, not majority support, as provided for the withdrawal agreement in Article 50. If the trade agreement includes services - which it must, if it is to protect the 'passport' rights of the London financial institutions, it will be a 'mixed' agreement, covering ground that goes outside the exclusive competence on external trade enjoyed by the EU. It will therefore also require ratification by national parliaments of the 27 remaining

member states of the EU. This takes a lot of time and has uncertain outcomes (as shown by the Canadian trade deal debacle with Belgium). While the trade agreement could (under the treaties) 
take effect even before it is fully ratified, it is highly unlikely that it will be concluded within two years, at least judging from the experience of similar deals with other third countries.

The distinction between the withdrawal agreement and the trade agreement has been obscured by the assumption - or, rather, the hope - that the two will be concluded simultaneously and will in practice be taken to be the same thing. But there is no guarantee that they will be concluded at the same time. Quite the contrary: it is near impossible that they will be so concluded, given the UK government's recent pronouncements.

If they cannot be concluded at the same time, then withdrawal will take place without any trade deal at all. It can happen either through the conclusion (by majority in the Council and the consent of the European Parliament) of the withdrawal agreement under Article 50, or through the automatic exit at the end of the two years in the event that an agreement is not reached. This is what is likely to happen in the spring of 2019. But if withdrawal happens without a trade agreement in place, then the minimum WTO rules will apply at once.

Is a temporary agreement bridging the gap between withdrawal and a new trade deal a realistic prospect? It is not, for legal reasons. Having the UK enter the EEA for a temporary period of time will require the UK and the EU concluding treaties with themselves and with all the members of the EEA. This would require ratification by all parties. Negotiating, signing and ratifying such an agreement cannot realistically be done within two years.

Could, instead, the UK's membership be scaled down for a transitional period? This would require amending the EU treaties, which is politically impossible, and in any event requires ratification by all member states of the EU, a process that also will take longer than two years. Such a treaty, by the way, would clearly engage the EU Act 2011 in the UK, which requires a referendum before an EU treaty amendment is ratified - so would require a second referendum on Brexit, which the government does not seem to want. So, given the nature of the UK's treaty obligations, a temporary arrangement seems to me as difficult to conclude as any permanent one.

In the absence of a temporary arrangement or a permanent trade deal, the UK will thus exit the single market at once. The relevant tariffs under that WTO framework were collected by the UK government in the chart below (prepared in the course of the Referendum campaign): 


\section{Tariff rates applied by the EU, by broad category of goods}

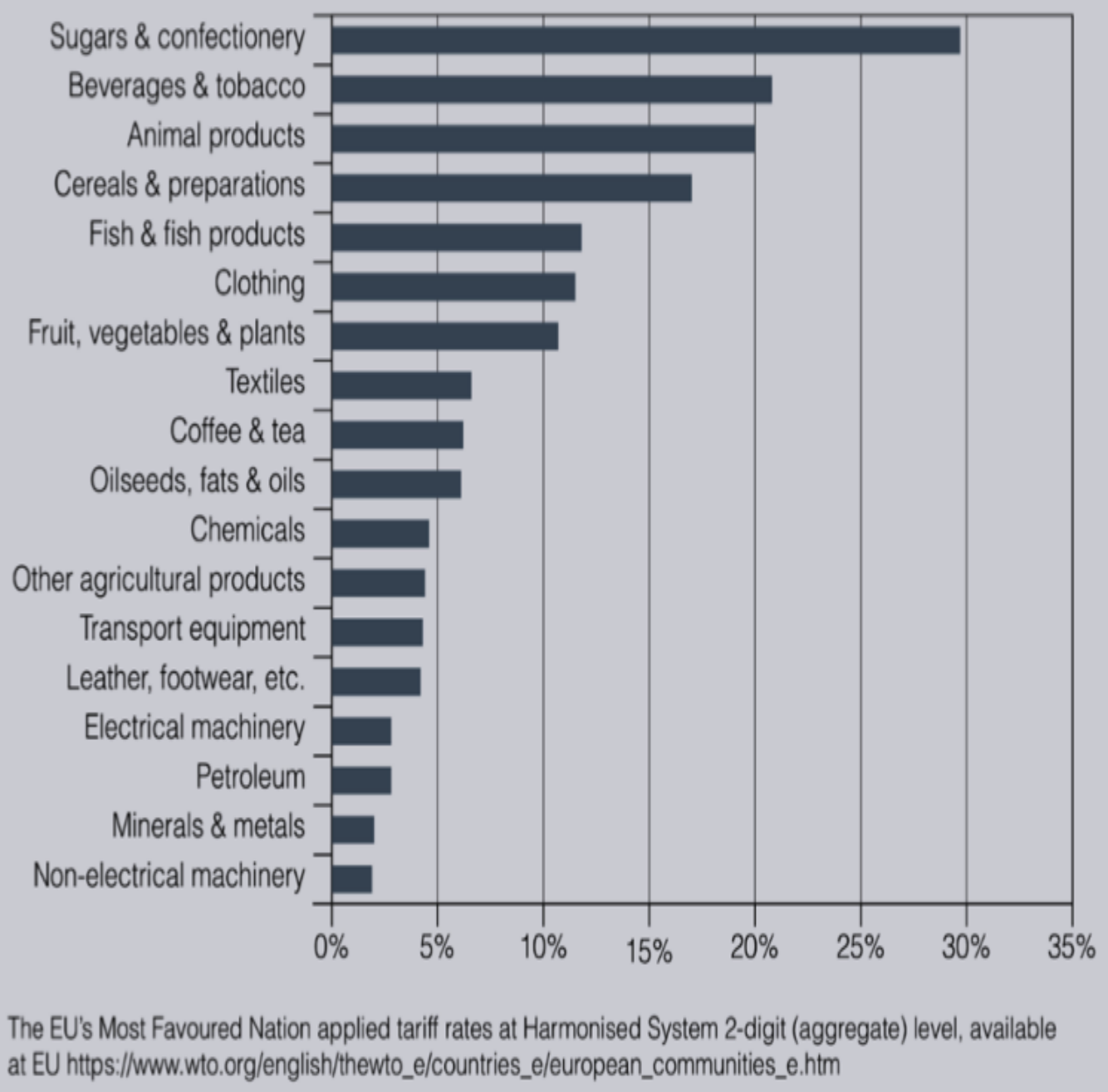

What does this mean? The financial services industry will have lost access to the single market at once. British products will have lost their immediate access to the single market and will be subject to formalities and tariffs. Immigration controls will have been fully re-introduced for UK nationals in the EU and for EU nationals in the UK. The economy will experience a sudden shock, with unknown consequences. We will not know if this is a permanent or a temporary arrangement, because this will depend on the - uncertain - possibility of a future trade agreement.

The political aspect of the process is unpredictable, but it is likely that a blame game will start on both sides. The UK government will blame the EU for holding it hostage and causing hardship out of vindictiveness. EU leaders will reciprocate by saying 'we told you so'. Anti-EU fever in the UK will rise in direct proportion to the economic hardship caused by the loss of access to the single market. Nationalism will deliver electoral success to the most populist ticket, either 
with Mrs May or another anti-EU leader in the 2020 general election. This is unlikely to be the start of a smooth process. This is, I think, what a failed Brexit looks like. It will be a time of rising anger, economic uncertainty, intense hardship and political instability.

For the unravelling to be avoided, we need a smooth transition to the new trade regime. But the reality is that it could only happen if the UK was ready to accept an extension of time. Page | 34 Negotiations must last longer if the trade agreement is to be ready at the point of withdrawal. Is this politically possible? In Mrs May's thinking, it seems not. The Prime Minister has said inexplicably, since she supported 'Remain' herself - that exiting the EU is a way for the UK to regain its 'sovereignty'. It is now a matter of great principle. She has stressed that everything needs to happen quickly, so as not to compromise the 'democratic will' of the British people. Withdrawal seems set for 2019 - a year before the general election.

This is then how Brexit will fail. Either through panic, or though inertia, or through incompetence, the UK will leave the EU exactly two years after giving notification. There will be no temporary deal, no permanent trade deal and no indication of a likelihood of such a deal. The UK will leave the single market quickly, without any period of transition, without giving anyone time to adjust, and without the hope of return.

Date of Publication: 27 October 2016 


\section{EU Prospectus Regulation: Some Out-of-the-Box Thinking}

\section{LUCA ENRIQUES}

One of the core initiatives of the European Commission's plan for a Capital Markets Union is its proposal to replace the existing legal framework for public offerings with a new regulation. The new regulation would bring some incremental changes to the existing framework, mainly in the direction of: (a) lowering the burdens for issuers (via broader exemptions for secondary offerings, an attempt to increase the use of shelf registration, and simplified prospectuses for small issuers); and (b) making prospectuses more retail investor-friendly (via shorter summaries and limits on the use of risk factors).

Both the ultimate rationale of the existing framework ("a high level of consumer and investor protection") and its building blocks would remain the same. Chief among them are, first, the idea of a prospectus to be drafted pursuant to detailed schedules identifying required disclosures item by item with a view to "removing asymmetries of information between [investors] and issuers;" second, pre-approval of the prospectus by competent authorities with a view to ensuring that the prospectus is complete, consistent and comprehensible.

It is a mystery why policymakers keep deluding themselves with the idea that issuer disclosure is a useful tool to protect retail investors. While reasonable minds may differ on whether mandatory disclosure does enhance the efficiency of capital markets by reducing the costs securities analysts and sophisticated investors have to bear in order to acquire and process the information they need for their investment decisions, a strong and convincing body of evidence exists showing that retail investors are unable to make better investment decisions by processing available information about an issuer (for a summary of the evidence see eg N Moloney, How to Protect Investors 291-96 (CUP, 2010)).

Policymakers, including in the EU, should explicitly recognize that, generally speaking, mandatory disclosure performs three different roles in three different contexts, as John Armour, Dan Awrey, Paul Davies, Jeffrey Gordon, Colin Mayer, Jennifer Payne and I argue in the book Principles of Financial Regulation (OUP, forthcoming). First, when an offer is made with a view to having securities admitted to trading on a regulated market (ie, in IPOs), mandating disclosure may only serve the purpose of laying down once and for all the information items that sophisticated buyers and investment analysts would anyway deem necessary in order to price the securities. 
Retail investors are not users of issuer disclosures in this context. Rather, they free ride on the mechanisms (usually in the form of the bookbuilding process) that lead to setting an IPO price reflecting available information. Second, when a bank or another financial intermediary places securities among clients without a proper parallel placement among institutional investors, mandatory disclosure's function is to provide investors with information which they may find useful, rather than to support investment decisions, as a basis for legal redress in case of misselling. Finally, for "fringe" offerings directly marketed to the investing public, the mandatory disclosure process, coupled with pre-approval of the prospectus, may serve the function of screening for fraud and amateurish initiatives (more likely the latter: given the relatively generous exemptions regime within the EU, fraudsters are unlikely to be caught by prospectus rules anyway).

If this framework holds, a more cost-effective way to reshape prospectus regulations would be the following. First of all, for IPOs (and non-exempt secondary offerings marketed in a similar way):

1. a requirement that the price of the offer to the public will be no higher than the price set for the offering reserved to institutional investors should be introduced (it is currently just a best practice within the EU);

2. required disclosures should cover the kind of information that securities analysts find relevant rather than working out the information needs of a mythological non-professional prospectus reader;

3. unlike in the current framework and in the Commission's proposal, there should be no need for:

a. mandating the inclusion in the prospectus of a summary, let alone for detailing its scope, length and contents;

b. prescribing which risk factors should be highlighted and which should be omitted;

c. laying out detailed rules on how to publish the prospectus;

\section{d. imposing any language requirement for prospectuses.}

Getting rid of the seemingly minor requirements referred to under (3) would reduce issuers' administrative costs, in addition to reducing their liability risk. ${ }^{1}$ In other words, a similar regime would be even more consistent with the goal of "mak[ing] markets work more efficiently and

\footnotetext{
1 A 2008 report commissioned by the European Commission estimated the administrative costs of preparing a prospectus for equity offerings at above €900,000; unsurprisingly, the European Banking Federation's response to the 2015 European Commission consultation on the Prospectus Directive review came up with a higher estimate, ranging from $€ 1.8 \mathrm{~m}$ to $€ 2.5 \mathrm{~m}$ for an IPO prospectus. Of course, the requirements mentioned above account for only a fraction of the costs of preparing a prospectus, but for smaller issuers even such a fraction could be a non-trivial expense.
} 
offer[ing] investors and savers additional opportunities to put their money at work", as the preamble to the prospectus regulation proposal reads.

A more controversial step, and most likely a political non-starter in the present regulatory climate, would be to move away from imposing itemized disclosure and securities regulators' preapproval of the prospectus, based on the argument that in IPO markets there is little role to play for these regulatory tools. In fact, one may wonder what the added value is of these regulatory requirements in a system where professional buyers are used to receiving a wealth of information and will want to continue receiving it: they will simply refuse to deal with (or discount securities offered by) an issuer omitting price-sensitive information. Underwriters themselves will make sure that such information is given.

No significant change is suggested here for direct "fringe" offerings, for which the risks of unscrupulous or outright fraudulent behaviour are high enough to make disclosure requirements a useful barrier to entry. But for offerings that are exclusively placed via banks and other regulated intermediaries relying on wide customer networks a good deal of simplification should be possible: here, it is the case that no reputation intermediary is available (in the case of self-placed products) and/or that no independent and sophisticated market players are involved in the pricing of the securities. The EU should not look too far for a better solution: key information documents (KIDs) similar to those required for PRIIPs would be suitable also for other bank-placed (non-structured) securities. While views may differ on the usefulness of KIDs as a tool for retail clients' investment decisions, a shorter document focusing on the financial instrument's characteristics and risks would make more sense than the pointlessly bulky prospectuses currently required. The document's focus, as hinted before, should be on the investment features that are relevant to assess whether the selling intermediary has violated conduct of business regulations, such as the suitability rule or rules on conflicts of interest, and thereby mis-sold the financial product.

To conclude, the Commission's proposal, while overall moving in the direction of reducing compliance costs, still reflects the misconception that disclosure regulation can help retail investors. Abandoning this misconception would allow for bolder steps in the direction of modernizing EU securities markets and facilitating capital raisings within the EU.

Date of Publication: 10 May 2016 


\section{About the Authors}

John Armour is the Hogan Lovells Professor of Law and Finance at the University of Oxford. Horst Eidenmüller is the Freshfields Professor of Commercial Law at the University of Oxford.

Pavlos Eleftheriadis is a Fellow in law at Mansfield College, Oxford and a barrister at Francis Taylor Building.

Luca Enriques is the Allen \& Overy Professor of Corporate Law at the University of Oxford.

Ariel Ezrachi is the Slaughter and May Professor of Competition Law at the University of Oxford.

Cheng Lim is a partner at King \& Wood Mallesons

Bruno Meyerhof Salama is a Professor of Law at the Fundação Getúlio Vargas School of Law in São Paulo, Brazil, where he heads the Center of Law, Economics \& Governance.

Calum Sargeant is a solicitor at King \& Wood Mallesons.

TJ Saw is a Co-founder of Ethcore.

Maurice Stucke is a Professor of Law at the University of Tennessee (Knoxville). 